\title{
RLUIPA: Where Are We Now? Where Are We Heading?
}

\author{
Alan C. Weinstein \\ Cleveland State University, a.weinstein@csuohio.edu
}

Follow this and additional works at: https://engagedscholarship.csuohio.edu/fac_articles

Part of the First Amendment Commons, Land Use Law Commons, and the Urban Studies Commons How does access to this work benefit you? Let us know!

\section{Repository Citation}

Weinstein, Alan C., "RLUIPA: Where Are We Now? Where Are We Heading?" (2004). Law Faculty Articles and Essays. 548.

https://engagedscholarship.csuohio.edu/fac_articles/548

This Article is brought to you for free and open access by the Faculty Scholarship at EngagedScholarship@CSU. It has been accepted for inclusion in Law Faculty Articles and Essays by an authorized administrator of EngagedScholarship@CSU. For more information, please contact research.services@law.csuohio.edu. 


\title{
Commentary
}

\section{RLUIPA:}

\section{Where Are We Now? Where Are We Heading?}

\author{
Alan C. Weinstein
}

Over the past three years, hardly a week has gone by without at least one newsstory announcing that a church, synagogue, or religious school-I'll use the term "church" from here on as a shorthand for all houses of worship or other religious institutions-is claiming that its right to religious freedom is being infringed by local government land use regulations in violation of the Religious Land Use and Institutionalized Persons Act. 'RLUIPA, a federal statute signed into law in September 2000, was enacted to restore to full vigor legal protection for religious freedoms that the Act's proponents argue had been seriously diminished by prior rulings of the U.S. Supreme Court. Since RLUIUPA went into law, churches in every section of the country have challenged zoning, historic preservation, and eminent domain decisions that they view as obstacles to how they develop or use their properties.

These challenges have been aided enormously by the litigation support efforts of national legal defense organizations focused on religious freedom-primarily the Becket Fund in Washington, D.C., which has ably assisted counsel for local churches in dozens of cases.

While some RLUIPA claims are ludicrous (e.g., Wisconsin Lutheran College's unsuccessful claim that complying with zoning in locating a proposed stadium would substantially burden its religious freedom), many disputes pose serious questions about how we balance the goals of land use regulations and the religious mission of churches in the context of a society experiencing rapid cultural and demographic change. This article addresses three basic questions about RLUIPA: How did we get here? Where are we now? and Where are we likely headed?

\section{HOW DID WE GET HERE?}

As recently as twenty years ago, neither churches nor local governments gave much thought to the federal courts, let alone federal statutes, when their disagreements about land use regulations resulted in litigation. Prior to 1983 , church challenges to zoning were normally brought in state courts, and it was not until 1993 that Congress first enacted legislation addressing "religious freedom." Moreover, just twenty years ago, neither the First Amendment nor guarantees of religious freedom in state constitutions played a critical role in church zoning cases, which almost invariably involved attempts to exclude churches from residential neighborhoods. State courts approached these challenges under a Substantive Due Process, rather than First Amendment, analysis. The majority of states viewed the exclusion of churches from residential neighborhoods as a violation of Substantive Due Process ${ }^{3}$ - because the moral values associated with churches outweighed any negative effects they might have on a surrounding neighborhood-while a minority held such exclusion could be a valid exercise of the police power so long as churches were not totally excluded from a community.
Alan C. Weinsteln is a Professor of Law and Urban Studies at Cleveland State University's ClevelandMarshall College of Law and Maxine Goodman College of Urban Affairs. He is a Reporter for Planning \& Environmental Law, co-author of LAND USE AND THE Constrtution, and Chair of the subcommittee on Land Use \& the First Amendment in the American Bar Association's Section of State \& Local Government Law.
1. Pub. L. No. $106-274$, codified at 42 U.S.C. $\$ 2000 \mathrm{cc}$ (2000).

2. See the Becket Fund's web site at

http://www. becketfund.org.

3. See, e.g., Jewish

Reconstructionist Synagogue of North Shore, Inc. v. Incorpo- rated Village of Roslyn Harbor 342 N.E.2d 534 (1975), cert. denied, 426 U.S. 950 (1976).

4. See, e.g., Corporation of Presiding Bishop of Church of Jesus Christ of Latter Day Saints v. City of Porterville, 203 P.2d 823, appeal dismissed 338 U.S. 805 (1949). 
Things began to change in 1983, however, with the first two federal Court of Appeals decisions involving the zoning of churches: Lakewood, Ohio, Congregation of Jehovah's Witnesses v. City of Lakewood and Grosz v. City of Miami Beach. ${ }^{6}$ Both the Sixth Circuit in Lakewood and the Eleventh Circuit in Grosz upheld zoning regulations against church challenges, using different variations of a First Amendment balancing test that weighed the competing interests of land use regulation and freedom of religion. Over the next several years, most federal courts applied the Grosz version of First Amendment analysis in cases involving church challenges to zoning ordinances and upheld the challenged land use regulations unless the facts showed discriminatory application or enforcement against a particular, and usually minority, religion.

\section{The Smith Decision and}

\section{Congressional/State Responses}

In 1990, the U.S. Supreme Court ruled in Employment Division 2 . Smith ${ }^{8}$ that the First Amendment's free exercise clause did not warrant "religious freedom" exemptions from "neutral laws of general application" for religious practitioners or institutions. The Smith decision meant that zoning codes, and other "general" laws that did not single out religion for unfair treatment, would, if challenged, be analyzed under the lenient "rational basis" test, rather than the extremely demanding "strict scrutiny" standard.

Smith was promptly denounced by a broad spectrum of religious and political groups that sought the aid of Congress to "restore" the religious protections they claimed the decision had removed. The Smith decision also prompted several state supreme courts to reaffirm the "strict scrutiny" approach to religious freedom claims brought on state constitutional grounds. And since 1990, over a dozen states have approved statutes or constitutional amendments comprehensively addressing religious freedom.

Three years after Smith, in Church of the Lukumi Babalu Aye, Inc. v. City of Hialeah, a unanimous U.S. Supreme Court ruled that Smith did not apply to laws that are "non-neutral"-i.e., where the law's object is to infringe upon or restrict practices based on their religious motivation. But the Hialeah decision did not abate the efforts of those seeking to "overturn" Smith, and that same year, Congress enacted the Religious Freedom Restoration Act (RFRA), a law intended to reinstate the strict scrutiny standard the Supreme Court had abandoned in Smith. RFRA proved to be short-lived, however. Four years after its enactment, the Supreme Court struck down the Act in City of Boerne v. Flores, "ruling that it exceeded the enforcement powers granted to Congress under the

Fourteenth Amendment and also violated fundamental Separation of Powers principles by allowing Congress, rather than the Supreme Court, to determine the meaning of the First Amendment's guarantees of religious freedom.

\section{Enactment of RLUIPA}

In the wake of the Boerne decision, religious and political groups again petitioned Congress to enact a religious freedom law, albeit one better suited to withstand judicial scrutiny. Efforts to enact a bill similar to RFRA failed in 1998 and 1999. In July 2000, however, two Senators at opposite ends of the political spectrum-Edward Kennedy (D-MA) and Orrin Hatch (R-UT)-proposed a more limited bill, focusing solely on land use and the religious rights of prisoners, that became RLUIPA. The bill's proponents claimed that RLUIPA, while still addressing the problems raised by $S$ mith, avoided the constitutional pitfalls of RFRA-a claim that those who opposed RFRA dis- puted. RLUIPA quickly gained broad support, unanimously passed both houses of Congress before the end of July, and was signed into law by President Clinton on September 22, 2000.

\section{A Broader View on "How Did We Get Here?"}

While disputes over the application of local zoning and historic preservation ordinances to churches and other "religious" uses of property are nothing new, the number and intensity of such disputes appear to have escalated in recent decades. Several factors have contributed to this trend. First, churches today are more likely to be perceived as inflicting negative effects on neighboring properties. Both new church construction and older churches seeking to expand existing facilities tend to be significantly larger than the churches of earlier eras and seek to use their facilities more intensively. Some congregations today seek to develop "big-box churches" in excess of 100,000 square feet, or "megachurches" occupying "campuses" of 20 acres or more. In addition to religious services, these churches house elementary and secondary education, child and senior day-care centers, and banquet halls; operate adult education classes and a variety of faith-based "support" programs; provide shelter for the homeless and meals for the indigent; and often have recreational facilities rivaling the best-equipped fitness clubs, motion-picture theaters, and coffee shops. As church activities expand to 12 or more hours per day, seven days a week, neighbors become increasingly concerned about the negative effects of increased traffic, parking, noise, and late-night activity on property values and lifestyle. When the church rivals the size of major commercial developments, the conflict between church and neighborhood can become acute. ${ }^{12}$

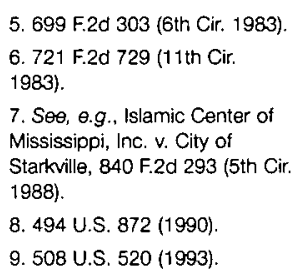

10. Pub. L. No. 103-41, codified at 42 U.S.C. $\S \S 2000 \mathrm{bb}-$ 200bb-4 (1994)

11. 521 U.S. 507 (1997).

12. See, e.g., Jim Schwab, Faith-Based Planned

Developments: Sorting Out the Uses, ZONING News, June 2003, and Jim Schwab, Zoning and
Big Box Religion, ZONING NEWS, November 1996; Jonathan D. Weiss and Randy Lowell Supersizing Religion: Megachurches, Sprawl and Smart Growth, 21 ST. LouIs U. Pub. L. Rev. 313 (2002). 
RLUIPA's reach is extremely broad due to its expansive definition

of what constitutes a protected "exercise of religion."

Of course, any new or expanded nonresidential development proposed for a residential neighborhood-the traditional locale for houses of worship-is likely to be opposed by neighbors. But this classic "NIMBY" phenomenon poses additional difficulties as regards churches because of recent changes in the manner in which Americans worship. Whereas previous generations attended church in their own neighborhood, commentators have noted that today, "religious institutions serve populations that are less and less centered in the geographic communities in which they are located." ${ }^{13}$ Thus, a proposed church is likely to be seen by its neighbors as providing them few benefits (since most of them will not be members), while imposing on them the burdens associated with more intense land uses, such as increased traffic, parking difficulties, noise, and the possibility of negative effects on property values.

Finally, the societal debate over the proper relationship between religion and government in American society-as seen in our media, at the ballot-box, and in our legislatures and courts-may also play a role in these land use disputes. In all of these forums, advocates for the strict separation of church and state argue that religion deserves no "special treatment" from government, while proponents of a larger role for religion in society contend that government should, at minimum, accommodate the needs of religious institutions and practitioners. At the local level, these differing perspectives can underlie disputes about the application of local zoning and historic preservation ordinances to churches.

\section{WHERE ARE WE NOW?}

How RLUIPA Affects Land Use Regulation RLUIPA affects local land use regulation by setting forth a "general rule" prohibiting a local government from imposing or implementing a "land use regulation" in a manner that imposes a "substantial burden" on the "religious exercise" of a person (including a religious assembly or institution), unless the government can demonstrate that imposition of the burden is in furtherance of a "compelling governmental interest" and is the "least restrictive means of furthering" that interest. RLUIPA defines "land use regulation" as a "zoning or land-marking law, or the application of such a law, that limits or restricts a claimant's use or development of land (including a structure affixed to land), if the claimant has an ownership, leasehold, easement, servitude, or other property interest in the regulated land or a contract or option to acquire such an interest."

RLUIPA's jurisdiction extends to cases in which:

- the substantial burden is imposed from a program or activity that is fed erally-funded, thus invoking the Spending Clause of the U.S. Constitution;

- the substantial burden, or its removal, affects interstate commerce, thus invoking the Constitution's Commerce Clause; or

- the substantial burden is imposed as a result of land use regulations that per mit the government to make "individ ualized assessments" regarding the use of the affected property, arguably invoking language in Smith that authorizes strict scrutiny when govern ment "has in place a system of indi vidual exemptions" but "refuse[s] to extend that system to cases of "reli gious hardship' ....",

Clearly, given its broad jurisdiction, the Act potentially could require that many, if not all, local government land use decisions affecting churches be subjected to strict scrutiny when challenged.

In addition, RLUIPA contains provisions mandating that local land use regulations must:
- grant "equal treatment" to a religious assembly or institution;

- not discriminate against any assembly or institution on the basis of religion or religious denomination; and

- not impose or implement a land use regulation that totally excludes religious assemblies from a jurisdiction or unreasonably limits religious assemblies, institutions, or structures within a jurisdiction.

The Act does not define the terms "religious assembly" or "religious institution," but their differing treatment (the ban on total exclusion applies only to "religious assemblies") suggests that "religious assembly" is the broader term, encompassing informal religious groups that worship or study in private homes and rented facilities.

RLUIPA's reach is extremely broad due to its expansive definition of what constitutes a protected "exercise of religion." The Act first defines this term generally as "any exercise of religion, whether or not compelled by, or central to, a system of religious belief," then sets forth a "Rule" that "the use, building, or conversion of real property for the purpose of religious exercise shall be considered to be religious exercise of the person or entity that uses or intends to use the property for that purpose."

Finally, RLUIPA also prescribes rules for legal claims brought under the Act. These include shifting the burden of persuasion to local government once a plaintiff produces prima facie evidence of a violation, and providing for the recovery of attorneys' fees under 42 U.S.C. $\$ 1988$.

What's Been Happening in RLUIPA Cases? About 30 RLUIPA land use challenges have produced reported decisions. A number of these, however, have been rulings on motions rather than decisions rendered after trial, and many of these rulings are still under appellate review. The
13. Marc D. Stern, Zoning for Churches: Guidelines, But No Magic Formula, 7 RiESPONSIVE Commintr No. 3 at 69,70 (1997).

14. 42 USCA $\S 2000 \mathrm{cC}-5(5)$.

15. Smith, 494 U.S. at 884 . 16. 42 USCA $\$ 2000 \mathrm{cC}-$ $5(7)(A) \&(B)$. 
author's weekly searches of Westlaw's news databases and Internet sources show that these reported decisions are just the tip of the iceberg: at least another 30 cases have been filed and many more lawsuits threatened. The RLUIPA claims asserted in these complaints and threatened suits have included:

- the right to host large numbers of persons at worship services or prayer groups conducted regularly in one's home;

- the right to establish a church or "social service" religious use in a specific zoning district where such uses are prohibited (a claim that has been made for all district types, from residential to industrial);

- challenges to regulations that arguably prohibit "religious uses" while allow ing other uses that have similar effects on neighboring areas;

- claims that land use regulations are an "effective ban" on religious uses; and, most generally,

- challenges to the denial of a zoning permit application or an application submitted under an historic preservation ordinance.

Local government reactions to RLUIPA claims have run the gamut, from immediate unconditional surrender at a church's mere mention of RLUIPA, to good-faith efforts at compromise, to willingness-perhaps even eagerness - to litigate the case all the way to the U.S.

Supreme Court. These differing reactions are partly explained by the facts of particular RLUIPA disputes, but a critical factor may also be how familiar local officials and their legal counsel are with RLUIPA cases decided to date.

It can be intimidating to local officials when a church threatens a RLUIPA claim, particularly when the church is represented, often pro bono, by prominent local counsel with expert assistance from the Becket Fund or other public interest attorneys. The fact that RLUIPA provides for an award of attorneys' fees to a winning church-even when the church's attorney handles the matter pro bonoonly adds to a city's concern when it faces a RLUIPA challenge. RLUIPA decisions to date, however, suggest that such concerns should not be overstated.

Several RLUIPA decisions, including a recent ruling from the Seventh Circuit Court of Appeals, have interpreted the Act far less broadly than its proponents claim is required. As a result, local governments have normally defeated RLUIPA challenges when they demonstrate that the restrictions placed on a church do not target religious uses for discriminatory treatment, are necessary to achieve valid land use regulatory goals, and do not force the church to cease religious worship. Conversely, churches have prevailed when local government is unable to meet these same criteria. In many of these cases, however, courts have found that the challenged land use regulation violated the Equal Protection Clause of the Fourteenth Amendment, and did not rule on the RLUIPA claims.

A recent decision of the Seventh Circuit in Civil Liberties for Urban Believers v. City of Chicago ${ }^{17}$ illustrates both outcomes. This case involved ongoing zoning disputes, dating back over a decade, between five religious groups and the city. The plaintiffs originally sued under RFRA, claiming that the city's zoning discriminated against churches because it required them to obtain special use approvals to locate in zoning districts where nonreligious assembly uses were permitted as of right. The RFRA claims were dropped after Boerne, but in February 2000, recognizing the validity of the plaintiffs' constitutional claims, the city amended its zoning ordinance to require that all assembly uses in the zoning districts in question obtain special use approvals, while exempting churches from having to show that their proposed use was "necessary for the public convenience." Despite this accommodation, the plaintiffs subsequently amended their complaint to include claims pursuant to RLUIPA. In 2002, the district court granted the city's motion for summary judgment, ruling that the February 2000 zoning ordinance amendments had removed any potential RLUIPA violation.

On appeal, the churches claimed that RLUIPA's broad definition of "religious exercise" meant that there was a "substantial burden" on religion whenever a land use regulation "inhibits or constrains the use, building, or conversion of real property for the purpose of religious exercise." The Seventh Circuit rejected the claim, arguing that this construction of RLUIPA's "substantial burden on religious exercise" language "would render meaningless the word 'substantial,' because the slightest obstacle to religious exercise incidental to the regulation of land use-however minor the burden it were to impose - could then constitute a burden sufficient to trigger RLUIPA's [strict scrutiny] requirement ...." Accordingly, the court held that, under RLUIPA, a land use regulation should be viewed as imposing a substantial burden on religious exercise only if it "necessarily bears direct, primary, and fundamental responsibility for rendering religious exercise-including the use of real property for the purpose thereof within the regulated jurisdiction generally-effectively impracticable." 19

The plaintiffs claimed that "the scarcity of affordable land available for development" in certain zones, "along with the costs, procedural requirements, and inherent political aspects" of the special use and other zoning procedures, imposed just such a substantial burden. The court rejected this claim. Noting that such conditions "are incidental to any 
The outcome of cases ... will rest largely on whether the court

high-density urban land use" and thus "may contribute to the ordinary difficulties associated with location (by any person or entity, religious or nonreligious) in a large city," the court found that "they do not render impracticable the use of real property in Chicago for religious exercise, much less discourage churches from locating or attempting to locate in Chicago," observing that each of the plaintiffs had been successful in finding a location. The court argued that were it to find a RLUIPA violation based on the time and expense required to meet land use permit requirements, then "RLUIPA would require municipal governments not merely to treat religious land uses on an equal footing with nonreligious land uses, but rather to favor them in the form of an outright exemption from land use regulations." The court sternly rejected any claim that RLUIPA mandates such favoritism: "Unfortunately for Appellants, no such free pass for religious land uses masquerades among the legitimate protections RLUIPA affords to religious exercise." The court also rejected plaintiffs' claims that the special use require-ment violated RLUIPA's nondiscrimination provisions, the Free Exercise Clause of the First Amendment, or the Equal Protection Clause of the Fourteenth Amendment.

While local governments should hail this ruling, it deserves two-not threecheers due to a split on the panel over the correct standard of review for a church's equal protection challenge. Two of the panel's three judges rejected the claim that equal protection challenges to land use regulation of churches should be subject to heightened scrutiny because such regulation "necessarily implicates the fundamental right of religious exercise." They cited the U.S. Supreme Court's well-known Cleburne decision as authority. Applying rational basis review, the majority held that Chicago had not violated the Equal Protection Clause of the Fourteenth Amendment.

The third member of the panel, Judge Richard Posner, dissented on this point. Judge Posner argued that the Cleburne Court had actually expanded the boundaries of rational basis review by using, and thus authorizing future use of, a "sliding scale" approach to rational basis review so that "discrimination against sensitive uses is to be given more careful, realistic, skeptical scrutiny by the courts than discrimination against purely commercial activities." Viewing the churches in this case as "no less sensitive a land use than homes for the mentally retarded" in Cleburne, Judge Posner argued "When government singles out churches for special regulation, as it does in the Chicago ordinance, the risk of discrimination, not against religion as suchChicago is not dominated by atheistsbut against particular sects, is great enough to require more careful judicial scrutiny than in the ordinary equal protection challenge to zoning." this standard, Posner argued that the challenged zoning provisions discriminated against "new, small, or impecunious churches" by making it more difficult and expensive to find locations they can afford, and he found no justification for such discrimination in the land use goals articulated by the city.

This disagreement between Judge Posner and the majority on the appropriate standard of review for a church's equal protection challenge echoes the larger debate between RLUIPA's proponents and opponents. RLUIPA proponents charge that many land use regulations constitute a "substantial burden" on the exercise of religion because they limit or prohibit a church's proposed use at a specific location, and also violate RLUIPA's "equal treatment" provision and/or the Equal Protection Clause because other arguably similar uses are not so limited. Judge
Posner, of course, would add that potential unequal treatment is shown, and heightened rational basis scrutiny justified, if land use regulations have a disparate impact on well-established and well-financed churches versus "new, small, or impecunious churches."

RLUIPA opponents argue that zoning codes challenged as restricting or prohibiting churches at some locations/districts normally provide other locations/districts where the church's proposed use is allowed, or perhaps even treated more favorably than similar uses. They cite, for example, the numerous codes that allow churches, and perhaps schools, as-of-right in residential districts, provided they meet the standards in the code, while other assembly uses-e.g., museums, theaters, meeting halls-are either prohibited entirely or treated as conditional or special uses. Arguing that the critical focus should be on the land use treatment of churches generally, not merely at the location preferred by the church itself, RLUIPA opponents claim that many challenged codes would withstand either a RLUIPA or equal protection challenge.

The outcome of cases presenting such conflicting claims, as shown in the Seventh Circuit decision, will rest largely on whether the court reads RLUIPA's "substantial burden" language expansively, which potentially subjects almost any locational or use restriction to strict scrutiny, or narrowly, which limits strict scrutiny to regulations that make religious exercise "impracticable" within the jurisdiction generally. Similarly, a court may apply the Cleburne rational basis test expansively, viewing all or some religious uses as deserving "more careful, realistic, skeptical scrutiny" and skeptically questioning the rationales underlying the challenged land use regulation, or narrowly, deferring to the legislative judgments in the challenged code so long as they are not facially irrational. 
Viewed thus, the track record for RLUIPA challenges has less to do with the specific facts of any given case and more to do with a given court's interpretation of the statute or parallel guarantees of religious liberty and equal treatment in the First and Fourteenth Amendments. From this perspective, the only prediction one can make about RLUIPA litigation is that a RLUIPA case is certainly headed to the U.S. Supreme Court for a ruling on the constitutionality of the statute, and this will likely occur sooner rather than later.

That said, before turning to cases that have ruled on the constitutionality of the Act, it is worthwhile to note other reported decisions.

Congregation Kol Ami v. Abington Township, a Third Circuit decision involving a Philadelphia suburb, shows that the Seventh Circuit is not alone in adopting a deferential stance towards local land use regulations. Kol Ami involved claims that Abington Township's zoning laws violated both the state and federal constitutions as well as RLUIPA. At issue was the township's denial of the congregation's request to covert a former convent for use as its synagogue. The congregation argued that their rights to equal protection were denied because there was no rational basis for the zoning decision prohibiting their proposed synagogue at this location. The township argued that the proposed use as a synagogue would create unacceptably high levels of traffic, noise, and other neighborhood disruptions as compared with the property's previous use as a convent. The congregation prevailed on a motion for summary judgment, the court finding that the township's zoning ordinance, as applied to the plaintiffs, was an unconstitutional denial of equal protection. Analyzing the congregation's claim under Cleburne, the district court found that uses "similar" to the proposed synagogue could be allowed as a special exception in the zoning district at issue, and thus the township's refusal to allow the synagogue was irrational and a denial of equal protection.

The Third Circuit vacated the district court's ruling and remanded for additional factual findings as to the compatibility of the proposed synagogue with the surrounding residential area, ruling that the district court had erred because it "overlooked the threshold step that must be taken under the City of Cleburne analysis-the court must first conclude that the two land uses are "similarly situated."

What intrigued observers about the Third Circuit's decision was not its disposition of the case, but rather what it might signal about the Circuit's then-anticipated ruling on the issue of RLUIPA's constitutionality in Freedom Baptist Church of Delaware County v. Township of Middletown (discussed below). The Kol Ami opinion strongly supported the right of local land use regulators to make appropriate distinctions among land uses, including the decision to exclude houses of worship from residential areas. Consider, for example, the following excerpts from the opinion:

[T] he federal courts have given states and local communities broad latitude to determine their zoning plans. Indeed, land use law is one of the bastions of local control, largely free of federal intervention....

A necessary corollary of the extensive zoning authority bestowed upon local municipalities, including the authority to create exclusively residential districts, is the authority to make distinctions between different uses and to exclude some uses within certain zones. Indeed, zoning is by its very design discriminatory, and that, alone does not render it invalid.
As long as a municipality has a rational basis for distinguishing between uses, and that distinction is related to the municipality's legitimate goals, then federal courts will be reluctant to conclude that the ordinance is improper ....

In view of the enormously broad leeway afforded municipalities in making land use classifications . . . it is strongly arguable that the Township's decision to group churches together with schools, hospitals, and other institutions is rationally related to the needs of these entities, their impact on neighboring properties, and their inherent compatibility or incompatibility with adjoining uses.

Finally, we do not believe land use planners can assume anymore that religious uses are inherently compatible with family and residential uses. See, e.g., Megaclutrches as Minitowns, NYT, F1, F6 (May 9, 2002). Churches may be incompatible with residential zones, as they 'bring congestion; they generate traffic and create parking problems; they can cause a deterioration of property values in a residential zone....'

On November 15, 2002, however, the district court approved a settlement between the parties in Middletown, in which the township agreed to change its zoning ordinances to comply with RLUIPA $^{31}$ and paid the church's $\$ 10,000$ in legal expenses. The settlement, of course, put the speculation instigated by Kol Ami to rest for the time being.

Murply v. Zoning Commission of the Toren of Milford ${ }^{3,3}$ is the only decision to date on the important issue of home worship. Here, neighbors complained because up to 40 people attended weekly Sunday afternoon "prayer meetings" in the Murphy's
23. 309 F.3d 120 (3 $3^{\text {rd }} \mathrm{Cir}$. 2002), vacating and remanding, Congregation Kol Ami v. Abington Township, 161 F. Supp.2d 432 (E.D. Pa. 2001).

24. Congregation Kol Ami v Abington Township, $161 \mathrm{~F}$. Supp.2d 432, 436 (E.D. Pa.
2001): see also Congregation Kol Ami v. Abington Township, 2001 WL 827492 (E.D. Pa. 2001)

(denying plaintiffs' motion for reconsideration)

25. Kol AMi, 309 F.3d at 125.

26. Id. at 135 .

27. 1d.
28. Id. at 136 (citing with approval, Lakewood, Onio Congregation of Jehovah's

Witnesses, Inc. v. City of Lakewood, 699 F.2d 303 ( $6^{\text {th }}$ Cir. 1983))

29. Id. at 143

30. Id. (footnote omitted)
31. The consent judgment may be accessed on the Becket Fund's RLUIPA wobsite at http://mww. ruipa.org/cases/FreedomBaptist ConsentJudgment.pdf.

32. Baptists, town settle suit over zoning law, PHILADELPHAA InOUIRER, November 16,2002 , at B2, 2002 W. 102158328 .
33. 148 F Supp 2d 173 (D. Conn. 2001); see also Murphy v. Zoning Comm'n of the Town of Now Milford, 223 F. Supp.2d 377 (D. Conn. 2002) (denying defendant's motion to dismiss). 
home, expressing concern that the large number of cars parked on the street jeopardized emergency vehicles' access and the safety of children playing in a cul-de-sac. Despite a finding by the town's zoning officer that cars were not blocking neighbors' driveways, the zoning commission ruled that such regularly scheduled meetings are not a customary accessory use in a single-family neighborhood, and issued a cease and desist order that limited to 25 the number of persons attending the prayer meetings. The Murphys did not appeal the order, choosing instead to bring a RLUIPA challenge.

The federal district court found that limiting the number of persons at prayer meetings to 25 imposed a substantial burden on the Murphys' free exercise rights because it would defeat the purpose of the meetings (to help those in need, including the "26th person"), and that the cease and desist order imposed a chilling effect on attendance at the meetings. Having triggered RLUIPA's strict scrutiny requirement, the Murphy court had little trouble finding that the town had shown "a compelling interest in protecting the health and safety of their communities through the enforcement of the local zoning regulations." But it ruled that the limit on the number of persons attending prayer meetings did not meet the least restrictive means test, arguing that the town should have placed a limit on traffic or on-street parking rather than the number of meeting attendees.

Cottonwood Christian Center v. Cypress Redevelopment Agency ${ }^{34}$ involved a RLUIPA challenge to both zoning and eminent domain actions. Here, the court granted the plaintiff's motion for a preliminary injunction prohibiting the redevelopment agency from acquiring the church's property under eminent domain for commercial development, which would have frustrated the church's plans to develop its property with a new 300,000-square-foot religious facility. Cottonwood spent a year assembling an 18-acre site for its proposed facility in a largely vacant 300 -acre area the city had targeted for redevelopment. Churches were a permitted use in the area, but the City of Cypress rejected the church's zoning application as incomplete because it did not contain design review studies the city wanted. The city then adopted a 45-day moratorium on new permits in the area to allow time to consider a new redevelopment plan. The moratorium was subsequently extended to bar the church's development for at least two years.

To avoid this bar, the church appealed the permit denial to the city council, which found that the requested design review studies were not required, deemed the application complete, and directed staff to undertake a review. But on February 28, 2002, the redevelopment agency offered to purchase the Cottonwood property for $\$ 14,583,500$. Cottonwood refused. The redevelopment agency then determined to acquire the land by eminent domain and the city filed an action in state court to condemn the land on May 29, 2002.

Cottonwood sued in January 2002, challenging the constitutionality of the land use decisions made by the agency and the city, and later amended its complaint to challenge the city's condemnation of its property. After denying the city's motion to dismiss, the federal district court ruled that RLUIPA's strict scrutiny standard of review governed Cottonwood's claim because the city's actions regarding the proposed church met both the commerce clause and "individualized assessments" jurisdictional bases in the statute. The court further ruled that even were jurisdiction under RLUIPA not invoked, strict scrutiny would still be appropriate under a free exercise clause analysis because the city's actions were "individualized assess ments" and there was "strong evidence that Defendants' actions are not neutral, but instead specifically aimed at discriminating against Cottonwood's religious uses." "The court also found that the city's zoning and eminent domain actions substantially burdened Cottonwood's exercise of religion because they made it impossible for the church "to practice its religious beliefs in its current location." ${ }^{36}$

The court then examined whether the city had satisfied its strict scrutiny burden by demonstrating that its actions were supported by a compelling governmental interest and were the least restrictive means for accomplishing that interest. The city had advanced two interests for refusing to grant Cottonwood's permit request and for condemning its property-preventing blight and generating revenue for the city. The court quickly dismissed the blight rationale, questioning whether the city's twelve-year-old finding of blight was still valid and arguing that the new 300,000 square-foot church would have eliminated any blight that did exist. The court was similarly dismissive with the city's claimed interest in revenue generation, noting that the city has maintained a 25 percent budget surplus without imposing additional taxes, and arguing more generally that by granting too much weight to a claimed interest in revenue generation, courts could allow cities to deny land use permits for any not-for-profit entity. Finally, the court ruled that even if it had found these interests compelling, the city had not utilized the least restrictive means to advance the interests, but rather had "done the equivalent of using a sledgehammer to kill an ant," noting again that construction of the proposed church would have alleviated any blight and that "the City has not demonstrated that there is no other way to provide for revenue without taking the property and preventing Cottonwood from building its church."

34. 218 F. Supp.2d 1203 (C.D.
Cal. 2002).
35. 1d. at 1224 .
36. 1d. at 1226 .
37. 1d. The Court also noted
that some of the church's activi-
ties would generate sales tax
revenues and that the large

numbers of people attending the 4,700-seat sanctuary would create a ready market for surrounding commercial developments.

38. 1d. at 1229 . 
Obviously RLUIPA, like its predecessor RFRA, is heading inex-

After the court granted Cottonwood its preliminary injunction, the church and the city skirmished back and forth a bit, but in October 2002, Cottonwood Christian Center and the city agreed that the church will sell its land where the city wanted retail development and will have the opportunity to purchase 28 acres on the Cypress Golf Course. Both sides also agreed to drop their lawsuits as part of the settlement.

In two other California cases, RLUIPA claimants have been less successful. In Ventura County Christian High Schoolv. City of San Buenaventura, a private religious school sought a preliminary injunction barring the city from enforcing its zoning requirements as applied to modular classrooms the school sought to erect on land leased from the public school district. The court denied the motion, finding that there was no evidence that the religious school had been treated unequally in comparison to secular applicants as regards approvals for modular classrooms, and that compliance with the approval requirements did not substantially burden the school's exercise of religious freedom.

In an unreported case, San Jose Christian College v. City of Morgan Hill, the court granted the defendant city's motion for summary judgment against a religiously affiliated college that had challenged the denial of its application to rezone a property for educational use. Here, the college had purchased a vacant former hospital intending to use the property for its college campus, but the city denied the rezoning application on the grounds that the property was the only site in the city zoned for hospital use and the college had not complied with the city's rezoning procedures. The college challenged both the procedural and substantive elements of the city's zoning code that governed its application for rezoning.
The court ruled that the RLUIPA claim failed because the college: (1) provided no evidence that the city's zoning code placed undue limitations on religious institutions, treated them unequally, or discriminated against them; and

(2) could not establish a prima facie case that the city's action imposed a substantial burden on its religious exercise. While this decision does not elaborate on the basis for the ruling on the substantial burden issue, this same court's prior ruling denying the plaintiff's motion for a preliminary injunction argued that the proposed use of the property as a college did not constitute an "exercise of religion" as that term has been defined in the Ninth Circuit's case law or as comprehended in RLUIPA.

In other reported decisions, courts have declined to reach, or have not yet reached, the RLUIPA claim. Some courts have ruled that the case could be resolved on other grounds, including the Free Exercise Clause ${ }^{42}$ or state law. ${ }^{45}$ In other cases, the courts found that the RLUIPA claim was not ripe, ${ }^{44}$ or that strict scrutiny would apply regardless of the RLUIPA claim, ${ }^{45}$ or that the RLUIPA claim had no jurisdictional basis, including where a city did not act pursuant to a zoning or landmarking law when it decided to develop a previously dedicated roadway located between two church-owned lots, ${ }^{46}$ or where a neighboring synagogue was seeking to intervene in a plaintiff telephone company's challenge to a city's denial of a permit to construct a transmission tower on a golf course.

\section{WHERE ARE WE HEADING?}

Obviously RLUIPA, like its predecessor RFRA, is heading inexorably and fairly quickly to the U.S. Supreme Court. There have already been a number of federal Courts of Appeal rulings on the constitutionality of RLUIPA's Institutionalized Persons provisions, with the Fourth, Seventh and Ninth Circuits upholding the Act, ${ }^{48}$ while the Sixth Circuit held that the Act was unconstitutional on Establishment Clause grounds. At this date, however, there are no Courts of Appeal rulings on the constitutionality of RLUIPA's land use provisions.

Several federal district court cases have addressed the constitutionality of RLUIPA's land use provisions. Freedom Baptist Church of Delaware County $v$. Township of Middletown, Westchester Day School v. Village of Mamaroneck, a further ruling in the Murphy case, and United States v. Maui County all upheld the land use provisions of the Act, as have several other less important decisions that will not be discussed here. ${ }^{54}$ Elsinore Christian Center v. City of Lake Elsinore, ${ }^{55}$ by contrast, is the only decision to date declaring RLUIPA's land use provisions unconstitutional by striking down both the "individualized assessments" and Commerce Clause jurisdictional bases of the statute.

These decisions vary in the degree to which they systematically analyze the contending positions articulated by RLUIPA's proponents and critics. To be fair, the district court judges may have declined a more probing examination of RLUIPA in an effort to speed each case on its way to the Supreme Court, since that is where the issue of its constitutionality must be resolved. For example, all parties in the Middletown case agreed that an immediate appeal on the question of RLUIPA's constitutionality would be beneficial, which allowed the district court to certify the question of RLUIPA's constitutionality to the Third Circuit as an interlocutory appeal; however, the parties reached a settlement before the case

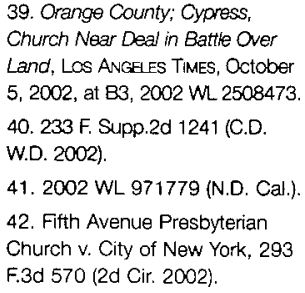
Presiding Bishop, 747 N.E.2d 131 (2001).

44. See Hale O Kalua Church v. Maui Planning Comm'n, $229 \mathrm{~F}$. Supp.2d 1050 (D. Haw. 2002) and State v. Willhite, $2002 \mathrm{WL}$ 452472 (Ohio App. 1Oth Dist.) 45. Hale O Kalua Church, $229 \mathrm{~F}$. Supp.2d at 1056

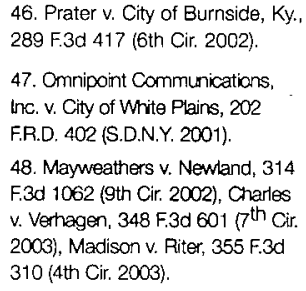

46. Prater $v$ City of Burnside, Ky 289 F.3d 417 (6th Cir. 2002).

47. Omnipoint Communications, inc. v. City of White Plains, 202 F.R.D. 402 (S.D.N.Y. 2001)

48. Mayweathers v. Newland, 314 F.3d 1062 (9th Gir. 2002), Charles v. Verhagen, 348 F.3d 601 ( $7^{\text {th }} \mathrm{Cr}$. 2003), Madison v. Riter, 355 F.3d 310 (4th Cir. 2003)

49. Cutter v. Wilkinson, 349 F.3d 257 (6 $6^{\text {th }}$ Cir. 2003)

50. 204 F. Supp.2d 857 \&E.D. Pa. 2002)

51. 280 F. Supp. $2 d 230$ (S.D.N.Y. 2003)

52. Murphy v. Zoning Comm'n of the Town of New Milford, 289 F. Supp.2d 87 (D. Conn. 2003)
53. 2003 WL 23148864 (D. Haw.)

54. See cases cited in Maui, 2003 WL 23148864 at 5 55. 291 F. Supp.2d 1083 (C.D. Cal. 2003) 
RLUIPA's Commerce Clause provision was also upheld in the

could be argued before the Third Circuit Court of Appeals.

\section{"Individualized Assessments"}

All of these decisions have addressed both the "individualized assessments" jurisdictional element of RLUIPA, which invokes Congressional jurisdiction under the Enforcement Clause of the Fourteenth Amendment, and the Commerce Clause jurisdictional element. The Middletown court dealt with this issue peremptorily. The court first baldly claimed, without argument or authority, that "zoning ordinances must by their nature impose individual assessment regimes." Next, after noting that Congress sought in this provision to codify the individualized assessments jurisprudence in Free Exercise cases, including Smith and City of Hialeah, the court concluded that RLUIPA "faithfully codifies the 'individual assessments' jurisprudence" announced by the Supreme Court and "is therefore not constitutionally exceptional." ${ }^{56}$ Based on that finding, the court argued that RLUIPA avoids the infirmities that doomed RFRA because it narrows its scope to land use and prison matters and simply tracks the Supreme Court's jurisprudence on these matters.

Neither Mamaroneck nor Maui County presented its own analysis on this issue; they simply adopted the Middletoren analysis." The Murphy decision, however, expanded on the analysis in Middletown. Specifically, the Murphy court noted that while RLUIPA may well extend protections beyond what is mandated by the Fourteenth

Amendment, that extended protection is within constitutional parameters because it closely tracks constitutional guarantees that the legislative history of the statute show are being violated. It also noted that the statute is not invalidated because its protections may "inci- dentally capture some conduct that, although close to the constitutional line, is not itself unconstitutional."

In contrast, the Lake Elsinore court engages in a far more extensive analysis of whether RLUIPA's "individualized assessments" provision does nothing more than codify the Supreme Court's "individualized exemptions" jurisprudence, and thus should not share RFRA's fate, and concludes that it does not. First, the court correctly notes that the Supreme Court's "individualized exemptions" jurisprudence merely stated that where exemptions from a general requirement are available, they may not be denied to those claiming an exemption on the ground of religious hardship. The court then argued that "[1] and use permitting is not an analogous case. In determining whether to issue a zoning permit, municipal authorities do not decide whether to exempt a proposed user from an applicable law, but rather whether the general law applies to the facts before it."

The Lake Elsinore decision next examines the two conditions that the Boerne decision set for an exercise of Congress's Fourteenth Amendment enforcement powers to be constitutional: "1) Congress must identify a 'widespread and persisting deprivation of constitutional rights' which it is acting to remedy or deter; and 2) there must be a congruence and proportionality between the injury to be prevented or remedied and the means adopted to that end." After calling the first requirement into doubt by noting the sparse legislative findings in support of RLUIPA, the court argues that the statute also fails the congruity and proportionality requirement because its broad definition of "religious exercise" extends strict scrutiny far beyond the exercise of core religious freedoms that had marked the Supreme Court's prior Free Exercise cases.

\section{Commerce Clause}

RLUIPA's Commerce Clause provision was also upheld in the Middletown and Mamaroneck decisions, ${ }^{62}$ but struck down by the Lake Elsinore court. The controversy over the validity of this provision stems from recent Supreme Court rulings that have invalidated Congressional action as extending beyond the authority granted under the Commerce Clause. The concern at the core of the Court's rulings in these cases is federalism: if not constrained in some principled way, Congress could assert its authority " $[\mathrm{t}] \mathrm{o}$ regulate Commerce ... among the several States," so broadly as "to completely obliterate the Constitution's distinctions between national and local authority." Since RLUIPA intrudes deeply and pervasively into local governmental authority, it has been challenged as exceeding what is permissible under the Commerce Clause.

In upholding RLUIPA's Commerce Clause provisions, however, both the Middletown and Mamaroneck courts stressed that Congress has extraordinarily broad authority over economic activity, which includes regulating intrastate activity based upon that activity's effect on interstate commerce. The Middletown court, citing the Telecommunications Act of 1996, further noted that RLUIPA was not the first instance in which Congress had sought to regulate matters that have traditionally been reserved to local zoning codes, rather than federal statutes.

The Lake Elsinore court, in contrast, argued that RLUIPA's Commerce Clause provision suffers from a potentially fatal flaw. "RLUIPA regulates land use law and not economic conduct. This, Congress may not do." The problem identified here, of course, is that because every land use regulation arguably has some effect on interstate commerce, if RLUIPA's Commerce Clause provision is

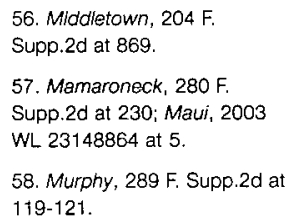

59. Lake Esinore, 29ł F. Supp.2d at 1098.

$60.1 d$. at 1100 , quoting Boeme.

61. Id. at 1101-02.

62. The Murphy case did not include a challenge to RLUIPA under the Commerce Clause.
63. U.S. CONST, art. $1, \S 8, \mathrm{cl} .3$

64. United States v. Morrison, 529 U. S. 598, $613(2000)$ (citing United States v. Lopez, 514 U.S. 549 at 564 (1995)).

65. Lake Elsinore, 291 F. Supp.2d at 1103 . 
upheld, there would not appear to be any principled way to restrain Congress from extending the Commerce Clause so far that it destroys the distinction between what is local and what is national, thus creating a centralized government.

\section{WILL RLUIPA MEET RFRA'S FATE?}

In Boerne, the Supreme Court ruled that Congress had violated basic principles inherent in the separation of powers among the branches of the federal government when it enacted RFRA.

Congress had relied on its broad grant of power under the enforcement clause of the Fourteenth Amendment in enacting RFRA, but the Court ruled that Congress had exceeded that authority by attempting to alter the constitutional right to free exercise of religion, rather than enforce it.

RLUIPA, like RFRA, seeks to negate the effect of the Smith decision and reinstate the compelling interest test. It differs from RFRA, however, in two key elements. First, Congress relied on its power under the Spending and Commerce Clauses, in addition to the Enforcement Clause of the Fourteenth Amendment, in enacting RLUIPA. Second, as opposed to RFRA's extensive reach, RLUIPA is limited to land use regulation and prisoners' rights. Are these changes sufficient to yield a different outcome when the Court reviews RLUIPA? In light of the Court's concern over the federalism implications of Congressional enactments under the Commerce Clause that intrude too deeply on local authority, RLUIPA appears vulnerable.

\section{CONCLUSION}

We are clearly in the midst of a dynamic environment-socially, politically, and legally - as regards the role of religion in our society, and RLUIPA reflects this in the context of potential conflicts between churches and land use regulation. Congress has attempted to empower churches when they choose where and how they build a sanctuary or assemble for worship, and to restrain local governments when they seek to apply zoning or landmark regulations to a church when the congregation objects. The Supreme Court will, sooner rather than later, decide whether this attempt is constitutional. In the meantime, how can local governments seek to avoid RLUIPA claims, and how do they evaluate their likelihood of prevailing if challenged?

\section{Avoiding a RLUIPA Claim}

Attempting to avoid a RLUIPA claim is certainly preferable to litigation. Local governments should examine their land use regulations affecting religious uses and how those regulations have been applied. At minimum, zoning ordinances should provide reasonable locational options for new, or expanding, houses of worship and such accessory religious uses as schools. While providing such options may not be particularly difficult in newer, less-developed communities, it can be a problem in older communities that are almost fully-developed. Such communities may find that their current zoning effectively precludes houses of worship from residential areas, because no sites are available, and also severely restricts their location in business and industrial areas, either because religious uses are seen as incompatible in such zones or out of concern for maintaining the city's tax base. Where locational options are effectively nonexistent or extremely limited, a local government should undertake a planning study that seeks to determine how it might accommodate the needs of religious uses without unduly harming surrounding property owners.

Local governments should also examine whether they are making adequate locational options for "social service" uses such as shelters for the homeless or victims of domestic abuse and facilities to feed the homeless and indigent. The claims of religious institutions that a local government must allow them to "minister to the poor" at a location of their choosing is blunted when a zoning code designates reasonable locational options for both secular and religious groups to provide such services.

Historic preservation ordinances should also be reviewed. As a rule, such ordinances should not allow landmark designation of the interior of a sanctuary without consent of the religious institution and should contain a "hardship" provision that would apply to any designated structure.

Finally, local governments should make sure that no religious denomination has been singled out for either favorable or disfavorable treatment in the land use regulatory process, and that applications from religious uses are treated no differently than similar applications from secular uses.

\section{Prevailing in a RLUIPA Case}

As previously discussed, a local government's likelihood of prevailing in a RLUIPA case often depends on how broadly or narrowly a court interprets RLUIPA. The circumstances of the dispute, however, are also important. Local governments are in a relatively strong position when they can demonstrate that they treat churches fairly as regards both the substantive and procedural aspects of their land use regulations, when they have no history of official animosity or discrimination towards churches generally and the challenging church in particular, and when the challenged regulation is based on a well-considered comprehensive land use, growth management, environmental protection, or historic preservation plan. Other facts that are generally favorable to local government include: when the church is a "big-box church" or "megachurch" that would have significant negative effects on neighboring properties; when the church has a history of ignoring reasonable land use regulations and/or violating safery and building code provisions; or when the church has refused to accept, or perhaps even discuss, a reasonable compromise. 


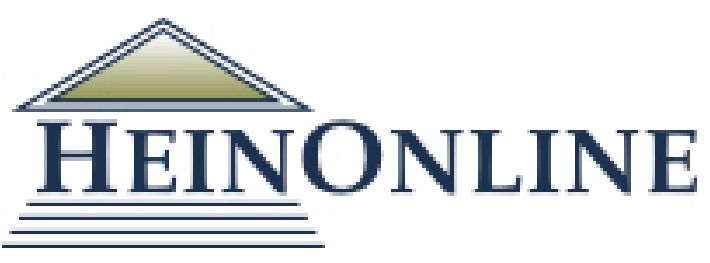

Content downloaded/printed from

HeinOnline

Wed Oct 16 14:35:55 2019

Citations:

Bluebook 20th ed.

Alan C. Weinstein, RLUIPA: Where Are We Now: Where Are We Heading, 56 Planning \& Envtl. L. 3 (2004).

ALWD 6th ed.

Alan C. Weinstein, RLUIPA: Where Are We Now: Where Are We Heading, 56 Planning \& Envtl. L. 3 (2004).

APA 6th ed.

Weinstein, A. C. (2004). Rluipa: Where are we now: Where are we heading. Planning

Environmental Law, 56(2), 3-12.

Chicago 7th ed.

Alan C. Weinstein, "RLUIPA: Where Are We Now: Where Are We Heading," Planning \& Environmental Law 56, no. 2 (February 2004): 3-12

McGill Guide 9th ed.

Alan C Weinstein, "RLUIPA: Where Are We Now: Where Are We Heading" (2004) 56:2

Planning \& Environmental L 3 .

MLA 8th ed.

Weinstein, Alan C. "RLUIPA: Where Are We Now: Where Are We Heading." Planning \& Environmental Law, vol. 56, no. 2, February 2004, p. 3-12. HeinOnline.

OSCOLA 4th ed.

Alan C Weinstein, 'RLUIPA: Where Are We Now: Where Are We Heading' (2004) 56 Planning \& Envtl L 3

Provided by:

Cleveland-Marshall College of Law Library

-- Your use of this HeinOnline PDF indicates your acceptance of HeinOnline's Terms and Conditions of the license agreement available at https://heinonline.org/HOL/License

-- The search text of this PDF is generated from uncorrected OCR text.

-- To obtain permission to use this article beyond the scope of your license, please use: Copyright Information

Use QR Code reader to send PDF to your smartphone or tablet device

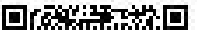

